\title{
Dietzia aurantiaca sp. nov., isolated from a human clinical specimen
}

\author{
Correspondence \\ P. Kämpfer \\ peter.kaempfer@umwelt. \\ uni-giessen.de
}

\author{
P. Kämpfer, ${ }^{1}$ E. Falsen, ${ }^{2}$ A. Frischmann ${ }^{3}$ and H.-J. Busse ${ }^{3}$ \\ ${ }^{1}$ Institut für Angewandte Mikrobiologie, Justus-Liebig-Universität Giessen, D-35392 Giessen, \\ Germany \\ ${ }^{2}$ Culture Collection University Göteborg, Department of Clinical Bacteriology, S-41346 Göteborg, \\ Sweden \\ ${ }^{3}$ Institut für Bakteriologie, Mykologie und Hygiene, Veterinärmedizinische Universität, A-1210 Wien, \\ Austria
}

\begin{abstract}
A Gram-positive, coccoid, non-endospore-forming actinobacterium (strain CCUG $35676^{\top}$ ) was isolated from cerebrospinal fluid from a 24-year-old woman in Gothenborg, Sweden. Based on pairwise $16 \mathrm{~S}$ rRNA gene sequence similarity studies, strain CCUG $35676^{\top}$ was shown to belong to the genus Dietzia and was most closely related to the type strains of Dietzia aerolata (99.3\%), Dietzia lutea (98.8\%), Dietzia schimae (98.5\%), Dietzia maris (98.5\%), Dietzia alimentaria (98.3\%) and Dietzia cercidiphylli (98.0\%). The major menaquinone was $\mathrm{MK}-8\left(\mathrm{H}_{2}\right)$. Major polar lipids were phosphatidylglycerol, diphosphatidylglycerol, phosphatidylinositol, an unidentified aminophospholipid (APL1), an unidentified phospholipid (PL1) and unidentified glycolipids (GL1 and GL3). Numerous other lipids were also detected. The fatty acid profile, comprising $\mathrm{C}_{16: 0}, \mathrm{C}_{17: 0}, \mathrm{C}_{18: 1} \omega 9 \mathrm{c}$ and 10-methyl- $\mathrm{C}_{18: 0}$ as major fatty acids, supported the affiliation of strain CCUG $35676^{\top}$ to the genus Dietzia. On the basis of the results of physiological and biochemical tests and DNA-DNA hybridizations, a clear phenotypic and genotypic differentiation of strain CCUG $35676^{\top}$ from the most closely related Dietzia species is possible. Strain CCUG $35676^{\top}$ represents a novel species, for which the name Dietzia aurantiaca sp. nov. is proposed, with CCUG $35676^{\top}\left(=\mathrm{JCM} 17645^{\top}\right)$ as the type strain.
\end{abstract}

At the time of writing, the genus Dietzia comprised 12 species with validly published names: Dietzia maris (Rainey et al., 1995), the type species; Dietzia natronolimnaea (Duckworth et al., 1998); Dietzia psychralcaliphila (Yumoto et al., 2002); Dietzia kunjamensis (Mayilraj et al., 2006); Dietzia cinnamea (Yassin et al., 2006); Dietzia schimae and Dietzia cerdiciphylli (Li et al., 2008); Dietzia papillomatosis (Jones et al., 2008); Dietzia lutea (Li et al., 2009); Dietzia timorensis (Yamamura et al., 2010); Dietzia aerolata (Kämpfer et al., 2010); and Dietzia alimentaria (Kim et al., 2011). Members of these species have been isolated from quite different sources, including various environmental and clinical materials (Duckworth et al., 1998; Yumoto et al., 2002; Yassin et al., 2006; Mayilraj et al., 2006; Kämpfer et al., 2010).

An orange-pigmented strain, CCUG $35676^{\mathrm{T}}$, was isolated on blood agar (Oxoid) at $37{ }^{\circ} \mathrm{C}$ from cerebrospinal fluid from a 24-year-old woman in Gothenborg, Sweden. The strain showed a Dietzia-like colony morphology. CCUG

The GenBank/EMBL/DDBJ accession number for the $16 \mathrm{~S}$ rRNA gene sequence of strain CCUG $35676^{\top}$ is FR821260.

A supplementary figure is available with the online version of this paper.
$35676^{\mathrm{T}}$ was further cultivated on tryptone soy agar (TSA) at $28{ }^{\circ} \mathrm{C}$. Cellular morphological properties and Gramreaction were observed by phase-contrast microscopy as described previously (Kämpfer \& Kroppenstedt, 2004).

The $16 \mathrm{~S}$ rRNA gene sequence of strain CCUG $35676^{\mathrm{T}}$ (a continuous stretch of $1390 \mathrm{bp}$ ) was studied as described previously (Kämpfer \& Kroppenstedt, 2004). Sequence alignment and analysis of the data were performed using the ARB software package (version December 2007; Ludwig et al., 2004) and the corresponding SILVA SSURef 100 database (release August 2009; Pruesse et al., 2007). Genetic distances based on pairwise comparisons were calculated with the ARB program and clustering was performed with the neighbourjoining method (Fig. 1) and with the maximum-likelihood method with fastDNAml (Olsen et al., 1994) without filters (Supplementary Fig. S1, available in IJSEM Online). In both trees, strain CCUG $35676^{\mathrm{T}}$ clustered with D. aerolata $\mathrm{Sj} 14 \mathrm{a}^{\mathrm{T}}$.

Sequence similarity calculations on the basis of a pairwise comparison indicated that the closest relatives of strain CCUG $35676^{\mathrm{T}}$ were the type strains of D. aerolata $(99.3 \%)$, D. lutea (98.8\%), D. schimae (98.5\%), D. maris $(98.5 \%)$, D. alimentaria $(98.3 \%)$ and D. cercidiphylli $(98.0 \%)$. 


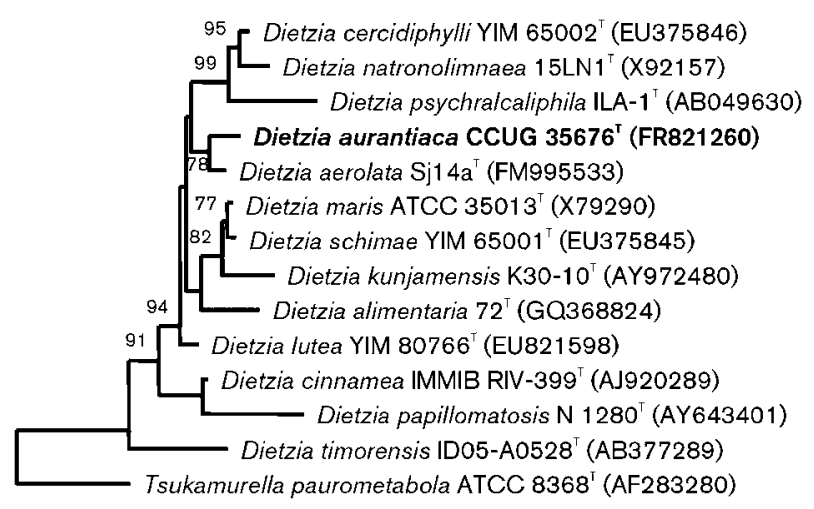

Fig. 1. Phylogenetic analysis based on 16S rRNA gene sequences available from GenBank/EMBL (accession numbers are given in parentheses). The phylogenetic tree was constructed using the ARB software package (version December 2007; Ludwig et al., 2004) and the corresponding SILVA SSURef 100 database (release August 2009; Pruesse et al., 2007). Tree building was performed using the neighbour-joining method. Bootstraps were calculated with 1000 replications; only values $>50 \%$ are shown. The sequence of Tsukamurella paurometabola ATCC $8368^{\top}$ was used as an outgroup. Bar, $0.1 \mathrm{nt}$ substitutions per nucleotide position.

Strains of other Dietzia species revealed $16 \mathrm{~S}$ rRNA gene sequence similarities $<98.0 \%$. Similar values were obtained for strain CCUG $35676^{\mathrm{T}}$ and the aforementioned species by using the pairwise similarity calculations based on the algorithm of the EzTaxon program (Chun et al., 2007), with variation of $0.1 \%$ at the most. The type strain of $D$. psychralcaliphila, which showed only $97.0 \%$ sequence similarity to strain CCUG $35676^{\mathrm{T}}$ on the basis of pairwise comparisons, showed $98.2 \%$ similarity with the algorithm of the EzTaxon program.

For quinone and polar lipid analyses, cells were grown in PYE medium $(0.3 \%$ peptone from casein, $0.3 \%$ yeast extract, $\mathrm{pH}$ 7.2). Quinones and polar lipids were extracted and analysed as described previously (Tindall, 1990a, b; Altenburger et al., 1996). Quinones were analysed by HPLC as described by Stolz et al. (2007). Total lipids were detected with molybdatophosphoric acid and further characterized by staining with ninhydrin (specific for free amino groups), molybdenum blue (specific for phosphate groups) and $\alpha$ naphthol (specific for sugars). The quinone system of CCUG $35676^{\mathrm{T}}$ was composed of menaquinones MK- $8\left(\mathrm{H}_{2}\right)(86 \%)$, MK- $7\left(\mathrm{H}_{2}\right)(12 \%)$ and MK-9 $\left(\mathrm{H}_{2}\right)(2 \%)$. A quinone system with dihydrogenated menaquinone $\mathrm{MK}-8\left(\mathrm{H}_{2}\right)$ as the predominant was given in the original genus description (Rainey et al., 1995) and this trait has also been reported for other Dietzia species (Jones et al., 2008; Kämpfer et al., 2010; Yamamura et al., 2010). Major polar lipids were phosphatidylglycerol, diphosphatidylglycerol, phosphatidylinositol, an unidentified aminophospholipid (APL1), an unidentified phospholipid (PL1) and unidentified glycolipids (GL1 and GL3; the latter exhibits an orange colour indicating a pigment that contributes to pigmentation of strain CCUG $35676^{\mathrm{T}}$ ) (Fig. 2). Furthermore, moderate to minor amounts of phosphatidylinositol mannoside, a third glycolipid and 11 unidentified lipids that could not be stained with any of the specific spray reagents applied were detected. This polar lipid profile contained several components that were also reported to be present in the most related species, D. aerolata (Kämpfer et al., 2010), e.g. phosphatidylglycerol, diphosphatidylglycerol, phosphatidylinositol, one phosphatidylinositol mannoside, glycolipid GL1 (corresponding to GL2 of D. aerolata) and lipid L2 (corresponding to L2 of $D$. aerolata). However, these two profiles were not identical. Both contained additional lipids that were not found in the profile of the other strain. These variations in the polar lipid profile indicate that strain CCUG $35676^{\mathrm{T}}$ should not be assigned to the species $D$. aerolata.

Fatty acid extraction and analysis were done as described previously (Kämpfer \& Kroppenstedt, 1996). MIDI software version 6.0 was used for peak identification. The fatty acid profile of strain CCUG $35676^{\mathrm{T}}$ was very similar to the profiles already described for closely related Dietzia species, but some minor differences could be observed (Table 1). However, the typical major fatty acids, i.e. $\mathrm{C}_{16: 0}, \mathrm{C}_{17: 0 \text {, }}$ $\mathrm{C}_{18: 1} \omega 9 c$ and 10 -methyl- $\mathrm{C}_{18: 0}$, could also be detected in strain CCUG $35676^{\mathrm{T}}$.

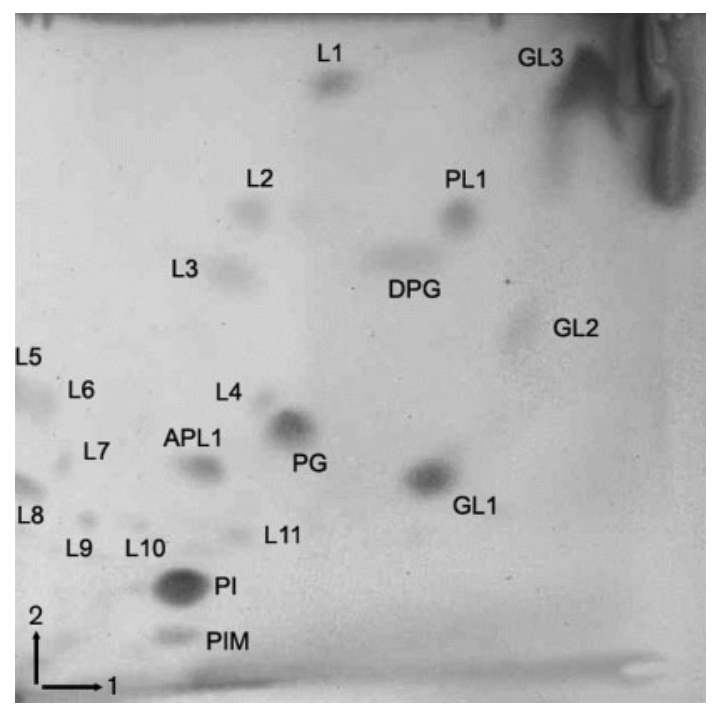

Fig. 2. Polar lipid profile of CCUG $35676^{\top}$ displayed after twodimensional TLC and detection with molybdatophosphoric acid. Directions of the first and second dimensions are indicated in the bottom left-hand corner. PG, Phosphatidylglycerol; DPG, diphosphatidylglycerol; PI, phosphatidylinositol; PIM, phosphatidylinositol mannoside; L1-L11, unknown polar lipids; GL1, 2, 3, unknown glycolipids; PL1, unidentified phospholipid; APL1, unidentified aminophospholipid. 
Table 1. Fatty acid profiles of strain CCUG $35676^{\top}$ and type strains of Dietzia species

Strains: 1, CCUG $35676^{\mathrm{T}} ; 2$, D. aerolata Sj14a ${ }^{\mathrm{T}} ; 3$, D. schimae YIM $65001^{\mathrm{T}} ; 4$, D. cercidiphylli YIM $65002^{\mathrm{T}} ; 5$, D. psychralcaliphila ILA-1 ${ }^{\mathrm{T}} ; 6$, D. natronolimnaea CBS $107.95^{\mathrm{T}} ; 7$, D. kunjamensis $\mathrm{K} 30-10^{\mathrm{T}} ; 8$, D. maris DSM $43672^{\mathrm{T}} ; 9$, D. lutea DSM $45074^{\mathrm{T}}$. Values are percentages of total fatty acids; all data were obtained with the MIDI system under the same conditions. Data for taxon 2 from Kämpfer et al., (2010); data for taxa 3 to 8 from Li et al. (2008); data for taxon 9 from Li et al. (2009). For unsaturated fatty acids, the position of the double bond is located by counting from the methyl $(\omega)$ end of the carbon chain; cis and trans isomers are indicated by the suffixes $c$ and $t$, respectively. - Not detected.

\begin{tabular}{|c|c|c|c|c|c|c|c|c|c|}
\hline Fatty acid & 1 & 2 & 3 & 4 & 5 & 6 & 7 & 8 & 9 \\
\hline $\mathrm{C}_{10: 0}$ & - & - & - & - & - & - & - & - & - \\
\hline $\mathrm{C}_{12: 0}$ & - & - & - & - & - & - & - & - & - \\
\hline $\mathrm{C}_{13: 0}$ & - & - & 0.2 & - & - & - & - & - & - \\
\hline $\mathrm{C}_{13: 0} 3-\mathrm{OH} /$ iso- $\mathrm{C}_{15: 1} \mathrm{H}$ & - & - & 0.5 & - & - & - & - & - & - \\
\hline $\mathrm{C}_{14: 1} \omega 5 c$ & - & - & 0.2 & - & - & - & - & - & - \\
\hline $\mathrm{C}_{14: 0}$ & 0.9 & 0.5 & 2.9 & 1.2 & 0.8 & 1.0 & 0.5 & 0.8 & 1.0 \\
\hline $\mathrm{C}_{13: 0} 2-\mathrm{OH}$ & - & - & 0.5 & - & - & - & - & - & - \\
\hline $\mathrm{C}_{15: 0}$ & 2.5 & - & - & - & - & - & - & - & 3.7 \\
\hline iso- $\mathrm{C}_{15: 1}$ & - & - & - & 0.4 & - & - & - & - & - \\
\hline iso- $\mathrm{C}_{15: 1} \mathrm{G}$ & - & - & 0.9 & - & 0.1 & - & - & - & - \\
\hline anteiso- $\mathrm{C}_{15: 1} \mathrm{~A}$ & - & - & 0.4 & - & - & - & - & - & - \\
\hline $\mathrm{C}_{15: 1} \omega 8 c$ & - & - & 0.8 & - & 0.2 & - & - & 0.2 & - \\
\hline $\mathrm{C}_{15: 1} \omega 5 c$ & - & - & 0.4 & - & - & - & - & 0.4 & - \\
\hline iso- $\mathrm{C}_{16: 0}$ & - & - & - & 1.6 & - & - & - & - & - \\
\hline $\mathrm{C}_{16: 1} \omega 9 c$ & - & - & - & 0.5 & 0.8 & - & - & - & 3.8 \\
\hline $\mathrm{C}_{16: 1} \omega 6 c / \mathrm{C}_{16: 1} \omega 7 c$ & 9.8 & 5.6 & 25.8 & 18.7 & 10.9 & 33.0 & 12.9 & 10.6 & 6.7 \\
\hline 10-methyl- $\mathrm{C}_{16: 0}$ & 0.5 & - & 0.8 & 1.1 & 0.3 & 0.7 & - & 0.6 & - \\
\hline $\mathrm{C}_{16: 0}$ & 21.7 & 22.7 & 22.2 & 18.9 & 16.9 & 14.1 & 13.0 & 15.3 & 15.4 \\
\hline anteiso- $\mathrm{C}_{17: 1} \omega 9 c$ & - & - & - & 0.9 & - & - & - & - & - \\
\hline $\mathrm{C}_{17: 1} \omega 8 c$ & - & 5.0 & - & 3.7 & 7.5 & - & 8.7 & 17.2 & 12.2 \\
\hline $\mathrm{C}_{17: 1} \omega 7 c$ & 0.4 & - & 19.2 & 2.2 & - & - & 7.6 & - & - \\
\hline $\mathrm{C}_{17: 1}$ anteiso $\mathrm{B} /$ iso I & - & - & 6.1 & - & 1.7 & - & - & - & - \\
\hline iso- $\mathrm{C}_{17: 0}$ & - & - & - & 0.2 & - & - & - & - & - \\
\hline anteiso- $\mathrm{C}_{17: 0}$ & - & - & - & 0.9 & - & - & - & - & - \\
\hline $\mathrm{C}_{17: 0}$ & 25.9 & 14.0 & - & - & 13.8 & - & 8.8 & 13.2 & 22.4 \\
\hline 10 -methyl- $\mathrm{C}_{17: 0}$ & 1.8 & 0.7 & 2.0 & 0.4 & 0.6 & 0.8 & 1.5 & 5.3 & 2.9 \\
\hline $\mathrm{C}_{18: 1} \omega 7 c$ & - & - & - & 3.5 & - & 4.5 & - & - & 1.7 \\
\hline $\mathrm{C}_{18: 1} \omega 9 c$ & 17.2 & 19.7 & - & 27.9 & - & 15.7 & 27.3 & 13.9 & 10.2 \\
\hline$C_{18: 3} \omega 6 c(6,9,12)$ & - & - & - & 1.4 & - & - & - & - & \\
\hline $\mathrm{C}_{18: 0}$ & 7.9 & 6.9 & - & - & 13.9 & - & - & 12.3 & 8.0 \\
\hline 10 -methyl-C $18: 0$ & 18.8 & 13.2 & 13.4 & 17.9 & 9.7 & 30.2 & 19.8 & 10.3 & 7.8 \\
\hline iso- $\mathrm{C}_{19: 0}$ & - & 1.1 & - & - & - & - & - & - & - \\
\hline anteiso- $\mathrm{C}_{19: 0}$ & - & 1.7 & - & - & - & - & - & - & - \\
\hline $\mathrm{C}_{19: 0}$ & 4.4 & 8.4 & - & - & 9.6 & - & - & - & 2.6 \\
\hline $\mathrm{C}_{20: 4} \omega 6,9,12,15 c$ & 1.9 & 1.4 & - & - & 11.7 & - & - & - & - \\
\hline $\mathrm{C}_{20: 1} \omega 9 c$ & 3.9 & - & - & - & - & - & - & - & - \\
\hline iso- $\mathrm{C}_{20: 0}$ & - & 0.9 & - & - & - & - & - & - & - \\
\hline$C_{20: 0}$ & 0.4 & - & - & 0.2 & - & - & - & - & - \\
\hline
\end{tabular}

The results of a comparative physiological/biochemical characterization using identical test conditions are given in Table 2 and the species description, on the basis of methods reported previously (Kämpfer et al., 1991). DNA-DNA reassociation experiments were performed with CCUG $35676^{\mathrm{T}}$ and D. aerolata Sj14a ${ }^{\mathrm{T}}, D$. schimae DSM $45139^{\mathrm{T}}, D$. cercidiphylli DSM $45140^{\mathrm{T}}$ and D. maris DSM $43672^{\mathrm{T}}$, which resulted in values of $15,26,34$ and $28 \%$, respectively, on the basis of the method of Ziemke et al. (1998).

The observed phenotypic differences and the genotypic differences in 16S rRNA gene sequences and DNA-DNA relatedness values justify the proposal of a novel species to accommodate the isolate.

\section{Description of Dietzia aurantiaca sp. nov.}

Dietzia aurantiaca (au.ran.ti.a'ca. N.L. fem. adj. aurantiaca orange-coloured).

Coccoid cells, about 1.0-1.5 $\mu \mathrm{m}$ in diameter. Gram-positive, oxidase-positive and catalase-positive showing an oxidative metabolism. Good growth occurs after 3 days of incubation on R2A agar, nutrient agar and TSA at $10-37{ }^{\circ} \mathrm{C}$. Colonies 
Table 2. Differential characteristics of strain CCUG $35676^{\top}$ and type strains of Dietzia species

Strains: 1, CCUG $35676^{\mathrm{T}} ; 2$, D. aerolata Sj14a ${ }^{\mathrm{T}} ; 3$, D. schimae YIM $65001^{\mathrm{T}} ; 4$, D. cercidiphylli YIM $65002^{\mathrm{T}} ; 5$, D. psychralcaliphila ILA-1 ${ }^{\mathrm{T}} ; 6$, D. natronolimnaea CBS $107.95^{\mathrm{T}}$; 7, D. kunjamensis $\mathrm{K} 30-10^{\mathrm{T}}$; 8, D. maris DSM 43672 ${ }^{\mathrm{T}}$; 9, D. cinnamea IMMIB RIV-399 ; 10, D. lutea DSM 45074 ${ }^{\mathrm{T}}$; 11 , D. papillomatosis $\mathrm{N} 1280^{\mathrm{T}}$. All data for taxa 1 to 3 are from this study; data for D. cinnamea IMMIB RIV-399 ${ }^{\mathrm{T}}$ are from Yassin et al. (2006); data for D. papillomatosis $\mathrm{N} 1280^{\mathrm{T}}$ are from Jones et al. (2008); data for D. lutea are from Li et al. (2009); other data are from Li et al. (2008). +, Positive; W, weakly positive; - , negative; ND, not determined.

\begin{tabular}{|c|c|c|c|c|c|c|c|c|c|c|c|}
\hline Characteristic & 1 & 2 & 3 & 4 & 5 & 6 & 7 & 8 & 9 & 10 & 11 \\
\hline Nitrate reduction & ND & $\mathrm{ND}$ & + & - & - & - & + & + & + & - & + \\
\hline $\mathrm{H}_{2} \mathrm{~S}$ production & ND & ND & - & - & + & + & + & - & ND & - & ND \\
\hline $\begin{array}{l}\text { Maximum } \mathrm{NaCl} \text { tolerance } \\
(\%, \mathrm{w} / \mathrm{v})\end{array}$ & 12 & ND & 15 & 10 & 10 & 10 & 15 & 15 & 12 & 15 & 8 \\
\hline \multicolumn{12}{|l|}{$\begin{array}{l}\text { Utilization as sole carbon } \\
\text { source: }\end{array}$} \\
\hline D-Adonitol & - & - & $-^{\star}$ & $-*$ & + & - & - & - & - & - & + \\
\hline D-Arabitol & $\mathrm{ND}$ & - & $-{ }^{*}$ & $-*$ & + & - & - & - & $\mathrm{ND}$ & - & $\mathrm{ND}$ \\
\hline L-Arabinose & + & - & $-{ }^{\star}$ & $+^{*}$ & - & - & - & - & - & + & + \\
\hline Inositol & - & - & $-^{*}$ & $-*$ & + & - & - & - & - & + & + \\
\hline Inulin & - & - & $-{ }^{\star}$ & - & - & - & + & - & $\mathrm{ND}$ & - & ND \\
\hline Lactose & ND & $\mathrm{ND}$ & + & + & + & + & + & - & - & - & + \\
\hline D-Lyxose & ND & $\mathrm{ND}$ & - & + & - & - & + & - & - & + & ND \\
\hline Maltose & - & - & $-{ }^{\star}$ & $+^{*}$ & + & + & - & + & + & - & + \\
\hline D-Mannose & - & + & $t^{*}$ & $+^{*}$ & + & + & + & - & ND & + & + \\
\hline Melezitose & $\mathrm{ND}$ & $\mathrm{ND}$ & - & - & + & + & $\mathrm{w}$ & + & - & - & + \\
\hline Melibiose & - & - & $-{ }^{\star}$ & $-*$ & + & + & + & - & ND & - & + \\
\hline $\mathrm{N}$-Acetylglucosamine & + & - & $-{ }^{*}$ & $-*$ & + & + & - & - & $\mathrm{ND}$ & - & $\mathrm{ND}$ \\
\hline Raffinose & $\mathrm{ND}$ & - & $-*$ & $-*$ & + & + & + & - & - & - & + \\
\hline L-Rhamnose & - & - & $-{ }^{\star}$ & $-*$ & - & - & + & - & - & + & $\mathrm{ND}$ \\
\hline
\end{tabular}

${ }^{\star}$ Results are congruent with those of Li et al. (2008) obtained with the method of Kämpfer et al. (1991).

grown on TSA are circular, convex and orange pigmented. Optimal temperature for growth is $30{ }^{\circ} \mathrm{C}$; growth occurs at $4-37{ }^{\circ} \mathrm{C}$ but not at 4 or $50{ }^{\circ} \mathrm{C}$. Optimal $\mathrm{pH}$ for growth is 7.0-8.0 and growth occurs at $\mathrm{pH}$ 5.5-12.5; however, it must be mentioned that growth at $\mathrm{pH}$ values $>10$ must be interpreted with care, because, even if the medium $\mathrm{pH}$ is adjusted to $12.5, \mathrm{CO}_{2}$ production will cause the $\mathrm{pH}$ to drop fairly quickly. The quinone system contains predominantly MK-8 $\left(\mathrm{H}_{2}\right)$. Major polar lipids are phoshatidylglycerol, diphosphatidylglycerol, phosphatidylinositol, an unidentified aminophospholipid (APL1), an unidentified phospholipid (PL1) and unidentified glycolipids (GL1 and GL3). Moderate to minor amounts of phosphatidylinositol mannoside, a third glycolipid and 11 unidentified lipids are also detected. Predominant fatty acids are $C_{16: 0}, C_{17: 0 \text {, }}$ $\mathrm{C}_{18: 1} \omega 9 c$ and 10-methyl- $\mathrm{C}_{18: 0}$. Also produces $\mathrm{C}_{15: 0}$ and $\mathrm{C}_{20: 1}$ in low amounts. Utilizes L-arabinose, cellobiose, Dglucose, fructose, $\mathrm{N}$-acetyl-D-glucosamine, ribose, acetate, azelate, fumarate, glutarate, DL-3-hydroxybutyrate, DLlactate, L-malate and pyruvate, but not D-galactose, Dgluconate, L-rhamnose, trehalose, D-xylose, D-adonitol, $i$-inositol, maltitol, D-mannitol, sorbitol, caprate, 4-aminobutyrate, L-alanine, asparagine, citrate, L-leucine or proline. Further carbon source utilizations (including differentiating characters determined under identical test conditions) are indicated in Table 2. 
The type strain is CCUG $35676^{\mathrm{T}}\left(=\mathrm{JCM} 17645^{\mathrm{T}}\right)$, isolated from human cerebrospinal fluid.

\section{Acknowledgements}

We are grateful to Gundula Will and the CCUG staff for excellent technical assistance and the Blood Department of the PHLS for submitting the isolate to the CCUG.

\section{References}

Altenburger, P., Kämpfer, P., Makristathis, A., Lubitz, W. \& Busse, H.-J. (1996). Classification of bacteria isolated from a medieval wall painting. J Biotechnol 47, 39-52.

Chun, J., Lee, J.-H., Jung, Y., Kim, M., Kim, S., Kim, B. K. \& Lim, Y. W. (2007). EzTaxon: a web-based tool for the identification of prokaryotes based on $16 \mathrm{~S}$ ribosomal RNA gene sequences. Int J Syst Evol Microbiol 57, 2259-2261.

Duckworth, A. W., Grant, S., Grant, W. D., Jones, B. E. \& Meijer, D. (1998). Dietzia natronolimnaios sp. nov., a new member of the genus Dietzia isolated from an east African soda lake. Extremophiles 2, 359-366.

Jones, A. L., Koerner, R. J., Natarajan, S., Perry, J. D. \& Goodfellow, M. (2008). Dietzia papillomatosis sp. nov., a novel actinomycete isolated from the skin of an immunocompetent patient with confluent and reticulated papillomatosis. Int J Syst Evol Microbiol 58, 68-72.

Kämpfer, P. \& Kroppenstedt, R. M. (1996). Numerical analysis of fatty acid patterns of coryneform bacteria and related taxa. Can $J$ Microbiol 42, 989-1005.

Kämpfer, P. \& Kroppenstedt, R. M. (2004). Pseudonocardia benzenivorans sp. nov. Int J Syst Evol Microbiol 54, 749-751.

Kämpfer, P., Steiof, M. \& Dott, W. (1991). Microbiological characterisation of a fuel-oil contaminated site including numerical identification of heterotrophic water and soil bacteria. Microb Ecol 21, 227-251.

Kämpfer, P., Langer, S., Martin, E., Jäckel, U. \& Busse, H.-J. (2010). Dietzia aerolata sp. nov., isolated from the air of a duck barn, and emended description of the genus Dietzia Rainey et al. 1995. Int J Syst Evol Microbiol 60, 393-396.

Kim, J., Roh, S. W., Choi, J.-H., Jung, M.-J., Nam, Y.-D., Kim, M.-S., Park, E.-J., Shin, K. S. \& Bae, J. W. (2011). Dietzia alimentaria sp. nov., isolated from a traditional Korean food. Int J Syst Evol Microbiol 61, 2254-2258.

Li, J., Zhao, G.-Z., Zhang, Y.-Q., Klenk, H.-P., Pukall, R., Qin, S., Xu, L.-H. \& Li, W.-J. (2008). Dietzia schimae sp. nov. and Dietzia cercidiphylli sp. nov., from surface-sterilized plant tissues. Int J Syst Evol Microbiol 58, 2549-2554.

Li, J., Chen, C., Zhao, G.-Z., Klenk, H.-P., Pukall, R., Zhang, Y.-Q., Tang, S.-K. \& Li, W.-J. (2009). Description of Dietzia lutea sp. nov., isolated from a desert soil in Egypt. Syst Appl Microbiol 32, 118-123.

Ludwig, W., Strunk, O., Westram, R., Richter, L., Meier, H., Yadhukumar, Buchner, A., Lai, T., Steppi, S. \& other authors (2004). ARB: a software environment for sequence data. Nucleic Acids Res 32, 1363-1371.

Mayilraj, S., Suresh, K., Kroppenstedt, R. M. \& Saini, H. S. (2006). Dietzia kunjamensis sp. nov., isolated from the Indian Himalayas. Int $J$ Syst Evol Microbiol 56, 1667-1671.

Olsen, G. J., Matsuda, H., Hagstrom, R. \& Overbeek, R. (1994). fastDNAmL: a tool for construction of phylogenetic trees of DNA sequences using maximum likelihood. Comput Appl Biosci 10, 41-48.

Pruesse, E., Quast, C., Knittel, K., Fuchs, B. M., Ludwig, W., Peplies, J. \& Glöckner, F. O. (2007). SILVA: a comprehensive online resource for quality checked and aligned ribosomal RNA sequence data compatible with ARB. Nucleic Acids Res 35, 7188-7196.

Rainey, F. A., Klatte, S., Kroppenstedt, R. M. \& Stackebrandt, E. (1995). Dietzia, a new genus including Dietzia maris comb. nov., formerly Rhodococcus maris. Int J Syst Bacteriol 45, 32-36.

Stolz, A., Busse, H.-J. \& Kämpfer, P. (2007). Pseudomonas knackmussii sp. nov. Int J Syst Evol Microbiol 57, 572-576.

Tindall, B. J. (1990a). Lipid composition of Halobacterium lacusprofundi. FEMS Microbiol Lett 66, 199-202.

Tindall, B. J. (1990b). A comparative study of the lipid composition of Halobacterium saccharovorum from various sources. Syst Appl Microbiol 13, 128-130.

Yamamura, H., Lisdiyanti, P., Ridwan, R., Ratnakomala, S., Sarawati, R., Lestari, Y., Triana, E., Kartina, G., Widyastuti, Y. \& Ando, K. (2010). Dietzia timorensis sp. nov., isolated from soil. Int J Syst Evol Microbiol 60, 451-454.

Yassin, A. F., Hupfer, H. \& Schaal, K. P. (2006). Dietzia cinnamea sp. nov., a novel species isolated from a perianal swab of a patient with a bone marrow transplant. Int J Syst Evol Microbiol 56, 641-645.

Yumoto, I., Nakamura, A., Iwata, H., Kojima, K., Kusumoto, K., Nodasaka, Y. \& Matsuyama, H. (2002). Dietzia psychralcaliphila sp. nov., a novel, facultatively psychrophilic alkaliphile that grows on hydrocarbons. Int J Syst Evol Microbiol 52, 85-90.

Ziemke, F., Höfle, M. G., Lalucat, J. \& Rosselló-Mora, R. (1998). Reclassification of Shewanella putrefaciens Owen's genomic group II as Shewanella baltica sp. nov. Int J Syst Bacteriol 48, 179-186. 